\title{
Sunn Hemp: A Legume Cover Crop with Potential for the Midwest?
}

\author{
D. Esther Shekinah ${ }^{1} \&$ James K. Stute ${ }^{2}$ \\ ${ }^{1}$ Research Scientist, Michael Fields Agricultural Institute, Wisconsin 53120, USA \\ ${ }^{2}$ Research Director, Michael Fields Agricultural Institute, Wisconsin 53120, USA \\ Correspondence: D. Esther Shekinah, Research Scientist, Michael Fields Agricultural Institute, W2493 County \\ Rd. ES. East Troy, Wisconsin - 53120, USA. E-mail: eshekinah@michaelfields.org
}

Received: July 2, 2018 Accepted: July 25, 2018 Online Published: August 20, 2018

doi:10.5539/sar.v7n4p63 URL: https://doi.org/10.5539/sar.v7n4p63

\begin{abstract}
Crops like corn and soybean occupy vast area in the Midwest, USA. When land is left fallow after the harvest of these crops, a number of degradation factors operate and bring about soil erosion, nutrient loss, decreased soil organic carbon, reduced biological activity and increase in weed biomass. Integrating cover crops (CCs) into this system would build benefits that the very system lacks. There are various CCs available, but leguminous CCs allows for reduced application of fertilizer nitrogen and builds the soil fixed atmospheric nitrogen. Winter CCs are restricted in the Midwest because of the short planting window which greatly minimizes the biomass accumulation. Warm season CCs would serve well here. Sunn hemp is one such tropical CC that grows well in temperate conditions too, without producing seeds. It comes with many benefits - including decreased soil erosion, improved soil organic carbon, increase in soil fixed nitrogen, higher biomass that adds organic matter and $\mathrm{N}$ to the soil, reduced weed density and weed biomass. The timing and method of termination influences the residue management. Going by the benefits it adds, sunn hemp is a viable warm season CC that can be grown in the Midwest and has great potential in fallows, prevented plant acres, areas of crop failure (planted and failed) and also in areas after the harvest of the short season small grains or processing crops. However, intensive research on sunn hemp is needed in the Midwest which is discussed.
\end{abstract}

Keywords: biomass, cover crop, CC termination, Midwest, nitrogen, sunn hemp, weed density

\section{Introduction}

Large stretches of land area in the upper Midwest, USA are dedicated to corn and soybean. These crops occupy the land for a short growing season and then the land remains fallow for the rest of the year, which opens it up for a number of degradation factors like loss of fertile topsoil through soil erosion, reduction in nitrogen due to leaching, decreases in the accumulation of soil organic carbon (SOC), decreased biological activity, and increased weed density and biomass. A more diversified rotation of additional crops including cover crops (CCs) could reduce these impacts.

\section{Why Cover Crops?}

Integrating CCs into such a system (corn - soybean) would build benefits that the very system lacks - improved soil organic matter, nitrogen fixation, increased nutrient cycling, improved biological diversity, reduced weed density and most of all, reduced soil erosion (Teasdale et al., 2007; Kaspar \& Singer, 2011). Apart from the environmental/ ecosystem services they provide (Blanco-Canqui et al., 2015), CCs are also now viewed as possible sources of agronomic service to the ecosystem - if they can enhance the performance and yield of the succeeding crop (Wortman et al., 2012a). Though various studies have demonstrated this, deriving maximum agronomic benefits with CCs will depend on the choice of the species and the management of residues (Wortman et al., 2012b). CCs grown as single species has an advantage over that of a mixture for ease of operations and termination (Mirsky et al., 2009). However, some farmers still choose CC mixtures to harvest the multi- various advantages of $\mathrm{N}$ fixation, differential harvesting of nutrients due to varied rooting systems and the soil layer depths they occupy, creation of a varied influence on soil porosity and infiltration, and the type of residue they leave on the surface leading to no-till, or the forage they can provide for the animals on the farm.

\section{Cover crop options}

Various CC options are available: cereals like winter rye, wheat, oat, sudan-sorghum grass, legumes like hairy 
vetch, red clover, crimson clover, cowpea, brassicas like rapeseed, white mustard, forage, either grown as single species or as mixtures. However, while most CCs are able to establish and grow well in tropical areas, some of these would not survive the harsh winters of the Midwest. Many of these would be less productive here than in other areas of the country, with late planting dates, shorter growing season and lower heat unit accumulation from harvest to planting and a very short growing season (Appelgate et al., 2017). It is a challenge to have successful establishment and growth of CCs in these regions.

Integrating legume $\mathrm{CCs}$ in these systems reduces the total dependence on fertilizer $\mathrm{N}$ and improves the environment by decreasing $\mathrm{N}$ losses (Reinbott et al., 2004). Winter legume CCs help improve soil physical properties, reduce soil erosion, conserve soil water, recycle nutrients and increase crop yield potential (Veenstra et al., 2007). However, the lack of favorable planting window and weather conditions means that the winter legume CCs often accumulate limited biomass. Warm season legumes may then be a desirable option.

Research on a few CCs that fit the corn - soybean system has been extensive. Although Natural Resource Conservation Service (NRCS) has listed some new CCs for this region, research has been limited in its ability to test effectiveness and scope of these new CCs. One such crop that deserves attention is sunn hemp. This is touted as one of the most efficient and effective CC for the Midwest, yet is largely untested.

\section{Sunn Hemp}

Sunn hemp (Crotolaria juncea L.) is a warm season legume that is grown for its ability to produce large biomass amounts and fix atmospheric nitrogen, thus improving the nutrient cycling of the soil while preventing soil erosion. It can also suppress weed density and biomass during the fallow period. By using this adapted tropical legume, the challenges of the use of winter cover crops can also be overcome. Though it grows all year round in Hawaii and is able to produce seeds there, it does not produce seeds in the Midwest. Sunn hemp is adapted to a wide range of soils and hence has attracted attention. It performs on poor sandy soils and also on soils with low fertility; however, it grows best on well-drained soils with a $\mathrm{pH}$ of 5 to 7.5 , and is resistant to nematodes (NRCS, 1999).

Sunn hemp is grown more in the southern states where there is warm temperatures, and cultivars being photoperiod sensitive, have a higher productivity there compared to other regions of the country. As a tropical legume, sunn hemp is able to produce larger quantities of biomass in a shorter time period than winter legumes from temperate zones while still providing agronomically important amounts of fixed nitrogen (Price et al., 2012). Sunn hemp is a legume that grows rapidly and can produce $5.6 \mathrm{t}$ biomass ha ${ }^{-1}$ and $122 \mathrm{~kg} \mathrm{~N}^{-1}$ in as little as 60 to 90 days. Close to $8 \mathrm{t} \mathrm{ha}^{-1}$ of biomass with $145 \mathrm{~kg}$ of N ha ${ }^{1}$ has been recorded in the south (Balkcom \& Reeves, 2005; Cherr et al., 2006), and an average of $9.6 \mathrm{t}^{\text {biomass }} \mathrm{ha}^{-1}$ at 45 to 60 days after planting in a 2-year study near Stillwater, Oklahoma (Warren et al., 2017).

Planting of sunn hemp is usually undertaken when the soil temperature is more than $50^{\circ} \mathrm{F}$, and this makes it an ideal cover crop to follow wheat harvest or after short-season summer crops harvested in August or early September. Being a photosensitive crop, it is killed by temperatures less than $28^{0} \mathrm{~F}$, and any delay in planting shortens the growing season and leads to a reduction in biomass yield. Therefore it is important to plant sunn hemp atleast 45 days before the first killing freeze in fall (Warren et al., 2017). It cannot produce viable seed in continental United States except for extreme southern locations of Florida and Texas; thus, eliminating its potential to be a weed (NRCS, 1999), but this elevates seed prices for the Midwest. Sunn hemp cultivar, "AU Golden" is suitable for production in temperate environments (Balkcom et al., 2011).

Sunn hemp as a CC has been consistently tested in the south, but has lacked the same intensity of research in the Midwest. Hence, it is of interest to the authors to build the case for sunn hemp as a CC. There are very few warm season legumes available as CCs; Sunn hemp can fill that void and fit in the cropping systems of the upper Midwest with benefits as indicated below.

\subsection{Potential Benefits}

\subsubsection{Nitrogen and Carbon}

Research has proved that SOC and crop yields are positively correlated, and therefore an increase in SOC through the addition of CC residues help increase crop yields (Blanco-Canqui et al., 2012). The SOC concentration was 1.25 times greater with sunn hemp on average than in non-CC plots in the top soil layer (Blanco-Canqui et al., 2011). Any increase in SOC improves the soil physical properties, increases water retention and infiltration, improves nutrient cycling and thereby stimulates crop growth. SOC also absorbs and filters nutrient loss in runoff (Rawls et al., 2003). Stallings et al. (2017) reported higher C:N ratio that led to greater immobilization with June and July planting of sunn hemp, and lower C:N ratio with May planting. At the 
0 to 5 -cm layer, increased soil nitrogen was recorded with cover grasses and sunn hemp compared to fallow (Garcia et al., 2013).

Sunn hemp added nitrogen to the soil as a legume crop, resulting in higher nitrogen uptake and yield of corn in $\mathrm{CC}$ plots compared to no cover plots. However, there was net increases of soil $\mathrm{N}$ that resulted in increased nitrate leaching. Muneoz- Carpena et al. (2008) recommended that when sunn hemp was used as CC, there should be reduction in the $\mathrm{N}$ fertilizer applied. In Kansas, averaged across four $\mathrm{N}$ application rates, soil total $\mathrm{N}$ concentration increased by $125 \mathrm{~kg} \mathrm{ha}^{-1}$ under sunn hemp compared with non-CC plots (Blanco-Canqui et al., 2012). Even though sunn hemp fixed $\mathrm{N}$ in the soil in significant amounts, in places of low rainfall, the beneficial effects of summer CCs may be limited. Sunn hemp contributed the equivalent of $58 \mathrm{~kg} \mathrm{ha}^{-1}$ of $\mathrm{N}$ fertilizer for corn planted the following spring (Balkcom \& Reeves, 2005), but N losses (most likely due to leaching) during the winter greatly reduced availability. Sunn hemp in combination with rye is able to scavenge residual $\mathrm{N}$ and could improve $\mathrm{N}$ use efficiency in organic systems and increase mineralizable $\mathrm{N}$ (Dabney et al., 2001).

The assumption that winterkilled CCs released N very fast is supported by Weinert et al. (2002), who documented that CCs which winterkill release and leach N more quickly than CCs which overwinter. Such experiments need to be evaluated in the upper Midwest too, to quantify the addition of $\mathrm{N}$ and increase in yield with sunn hemp as cover crop.

\subsubsection{Weed Suppression}

Compared to mowing CCs, termination with a roller-crimper results in uniform distribution of residues leading to improved weed suppression, prolonged residue decomposition and reduced fuel and labor inputs (Creamer \& Dabney, 2002). For organic farmers, alternating this practice with crops that are established with tillage avoids selection for perennial weeds (Rasmussen et al., 2014; Smith et al., 2011). Volunteer CCs resulting from incomplete termination with mechanical rolling can be problematic in subsequent crops and may impact the benefits of organic rotational no-till. But with sunn hemp, since the potential to seed is next to nonexistent, there is no problem of the CC becoming a weed (NRCS, 1999). CCs need to produce a biomass in the range of 5 to $8 \mathrm{t}$ $\mathrm{ha}^{-1}$ in order to form an effective layer of mulch to prevent weeds from establishing (Mohler \& Teasdale, 1993). Sunn hemp has been recorded to produce nearly 7 to $8 \mathrm{t} \mathrm{ha}^{-1}$ of biomass in the Midwest regions. That makes it a potential CC capable of weed control after the cash crop either in the summer or fall. In Georgia, Bradley et al. (2015) reported lower grass weed biomass with sunn hemp, which also needs to be studied in the Midwest.

\subsubsection{Biomass $\mathrm{N}$}

Nitrogen fixing summer or tropical legume CCs such as sunn hemp that produce high biomass may improve soil properties more rapidly and have a greater effect on increasing crop yields. Planting CCs early, such as after corn silage or wheat or into standing crops just before it reaches maturity (Ruis \& Blanco-Canqui, 2017) is one way of CC management. For example, when leguminous CC followed wheat in Kansas, biomass levels were $7 \mathrm{t} \mathrm{ha}^{-1}$ for sunn hemp and $5.3 \mathrm{t} \mathrm{ha}^{-1}$ for late maturing soybean (Blanco-Canqui et al., 2011). Results of the experiments conducted by Blanco-Canqui et al. (2012) indicated that summer CCs, particularly sunn hemp, can return significant amounts of residues in a short period of about $12 \mathrm{wks}$. The increased height of sunn hemp may also be beneficial for shading and smothering weeds. Such higher residue input from sunn hemp has been reported from other regions as well (Mansoer et al., 1997; Balkcom \& Reeves, 2005; Schomberg et al., 2007).

Cultivar "Tropic Sun", which has been most extensively studied, has been shown to produce $5.8 \mathrm{t} \mathrm{ha}^{-1}$ biomass and contribute 135-145 $\mathrm{kg} \mathrm{ha}^{-1} \mathrm{~N}$ in a 9-12-week period (Mansoer et al., 1997). High biomass production within a short period enables sunn hemp to serve as a summer CC between warm-season harvest and cool-season planting (Mosjidis \& Rehtji, 2011), with the added benefit of reduced fallow weed population and density. A winter CC such as rye, could sequester N produced from decomposing sunn hemp biomass (Balcom \& Reeves, 2005), making this system a profitable one. Three year mean biomass added to the soil from sunn hemp in a study in Georgia ranged from 6.9 to $9.8 \mathrm{t} \mathrm{ha}^{-1}$ while that of crimson clover ranged from 3.5 to $4.9 \mathrm{t} \mathrm{ha}^{-1}$. This increased biomass contributed to improvement in soil structure and fertility (Hubbard et al., 2013). In a planting date study at Wisconsin, a maximum biomass of 5.7 to $7.4 \mathrm{t} \mathrm{ha}^{-1}$ was obtained (Stute, 2017). Repeated use of sunn hemp as a CC in conservation tillage systems could be expected to improve soils in the region due to the large amount of residue produced in a short growing period (Schomberg et al., 2007), and thus leads to the argument for sequential CCs.

\subsubsection{Crop Yield}

Legume CCs like sunn hemp are the most reliable means to enhance cash crop yields compared with fallows or other CC species (Snapp et al., 2005). Sunn hemp when used as summer CC brought about changes in soil 
properties which increased the yield of crops that followed (Blanco-Canqui et al., 2011 \& 2012). This is in conformity with the results of Balkcom and Reeves (2005). Increase in crop yields due to the beneficial effects of CCs like sunn hemp can be particularly greater at or below $66 \mathrm{~kg} \mathrm{ha}^{-1}$ of $\mathrm{N}$ application, which suggests that CCs may be supplementing extra $\mathrm{N}$ to the crop for higher gains in yield while also removing competition from weeds, reducing input costs of herbicides and fertilizers, and gainfully using soil moisture. Results from Kansas showed that the mean increase in grain yield of corn as a result of including cowpea, pigeonpea, sunn hemp, double cropped soybean, and double cropped sorghum in the rotation over fallow system with $0 \mathrm{~kg} \mathrm{~N} \mathrm{ha}^{-1}$ was 78 , 91, 66, 72 and 12\% respectively (Mahama et al., 2016). Fertilizer $\mathrm{N}$ replacement values for cowpea, pigeonpea, sunn hemp, double-cropped soybean, and double-cropped grain sorghum were $53,64,43,47$, and $-5 \mathrm{~kg} \mathrm{~N} \mathrm{ha-1,}$ respectively.

When sunn hemp was grown as summer $\mathrm{CC}$, particularly at $\mathrm{N}$ application rates that were low, Blanco-Canqui et al. (2012) reported an increase in crop yields. When no nitrogen was applied, sunn hemp increased sorghum yield by 1.18 times in 2003, 1.54 times in 2005, 1.32 in 2007, and 1.43 in 2009 as compared to non-CC plots. This difference in sorghum yield between sunn hemp and non-CC plots at $0 \mathrm{~kg} \mathrm{~N} \mathrm{ha}{ }^{-1}$ tended to increase gradually with time after summer CC establishment. However, CCs may or may not increase yields of subsequent crops (Andraski \& Bundy, 2005).

\subsection{Termination}

Termination method and residue management can influence $\mathrm{N}$ mineralization, soil nutrient loss and availability, crop N uptake, weed communities and soil moisture availability (Mirsky et al., 2009; Parr et al., 2011; Wortman et al., 2012b). Yield is typically expected to improve with legume CCs, and when loss occurs, it is attributed to incomplete cover crop termination, increased moisture utilization by CCs leading to moisture deficit, or nutrient immobilization (Mischler et al., 2010a). Liebl et al. (1992) found that transpiration reduced available soil moisture during dry periods, but following no-till termination, $\mathrm{CC}$ residue conserved soil moisture relative to a no-till system without CCs. Given that the driest portion of the growing season in the western Corn Belt typically occurs after CC growth (i.e., June-August), potential soil moisture savings offered by the residue (post-termination) throughout the growing season may negate moisture deficits observed during $\mathrm{CC}$ growth (Wortman et al., 2012b).

Delaying termination until approximate planting of the following crop creates a more synchronous relationship between the sunn hemp residue mineralization and crop demand (Stallings et al., 2017). Starting with a CC and then switching from conventional till to no till is more likely to ensure success and to maintain economic crop yields (Islam \& Reeder, 2014). One method of reducing tillage frequency in organic grain production is CC based rotational no-till (Mirsky et al., 2012), which involves growing high-biomass CCs, terminating them with a roller-crimper, and no-till planting cash crops into the weed-suppressive mulch (Keene et al., 2017). It is also necessary to make sure that the $\mathrm{CC}$ is susceptible to control with a roller-crimper so that it does not compete with the cash crop (Bernstein et al., 2011; Mischler et al., 2010b). Blanco-Canqui et al. (2012) concluded that inclusion of summer legume CCs like sunn hemp in no-till systems brings about many benefits like improved soil physical properties, increased SOC and N, and also reduced application of fertilizer N.

Sunn hemp planted in August or September following an early season summer cash crop would be best served by allowing freezing temperatures to terminate it. Mowing and crimping are other non-chemical methods of termination and many farmers have reported good success with it. Growing sunn hemp as CC and roller crimping it would therefore lead to no till corn, with additional benefits of improved $\mathrm{N}$ status of the soil. This usually may require multiple passes with roller/crimper to sufficiently kill the cover crop. This system can greatly benefit organic no-till corn while conventional farmers can also be benefitted by growing sunn hemp. When CC and manure additions are coupled, an organic reduced tillage system can sequester increased SOC over a no-till system after several years (Teasdale et al., 2007).

\subsection{Potential Applications}

There are few good warm season legume CC options for the upper mid-west, yet several applications where it could be used. Applications include summer fallow, prevented plant acres, cases of crop loss, and after harvest of short season crops such as small grains and processing crops.

Land is often left fallow in organic production systems, either as a planned soil building strategy or to remediate soils from physical degradation caused by excessive tillage or to reduce weed populations (Clark et al., 2017). Large areas of the upper Midwest are also unplanted annually due to the stringent cut-off dates associated with federally supported crop insurance (United States Department of Agriculture (USDA) Handbook, 2018). Wisconsin, for example, has averaged 76,142 acres annually in the past 10 years for prevented plant acres, and 


\section{6,132,295 acres for planted and failed (USDA, 2018).}

We can anticipate increases in prevented plant acres and storm damaged crops as storm intensity and frequency increase. More extreme temperatures and precipitation can prevent crops from growing. Extreme events, especially floods and droughts, can harm crops and reduce yields. High nighttime temperatures affected corn yields across the U.S. Corn Belt in 2010 and 2012 (Environment Protection Agency (EPA), 2017, Iizumi \& Ramankutty, 2015). Sunn hemp would be a right fit under such situations. It can be either grown as a single crop or in sequential cover cropping.

Finally, harvest of short season crops such as small grains and processing idle cropland for a significant portion of the growing season with cover crops has beneficial effects. Planting a warm season legume like sunn hemp to capture unused solar radiation could provide many associated benefits as described earlier.

\section{Conclusion}

Though there is potential in using sunn hemp in the organic no till corn production, its performance depends heavily on the production of biomass, and formation of a mulch layer to effectively control weeds. Sunn hemp as a legume $\mathrm{CC}$ fixes atmospheric $\mathrm{N}$, increases the soil nutrient availability, improves the SOC, reduces soil erosion and serves the ecosystem. It can be either cultivated as a warm season CC or a component of sequential cover cropping in organic transitions or no till corn. In all this, the proper stage of crimping is very important. There has not been much studies in that direction on sunn hemp, especially in the upper Midwest of USA, and therefore, needs research and documentation.

\section{References}

Andraski, T. W., \& Bundy, L. G. (2005). Cover Crop Effects on corn yield response to nitrogen on an irrigated sandy soil. Agronomy Journal, 97, 1239-1244. https://doi.org/10.2134/agronj2005.0052

Appelgate, S. R., Lenssen, A. W., Wiedenhoeft, M. H., \& Kaspar, T. C. (2017). Cover crop options and mixes for Upper Midwest corn-soybean systems. Agronomy Journal, 109(3), 968-984. https:doi.org/10.2134/agronj2016.08.0453

Balkcom, K. S., \& Reeves, D. W. (2005). Sunn Hemp utilized as a legume cover crop for corn production. Agronomy Journal, 97, 26-31. https://doi.org/10.2134/agronj2005.0026

Balkcom, K. S., Massey, J. M., Mosjidis, J. A., Price, A. J., \& Enloe, S. F. (2011). Planting date and seeding rate effects on sunn hemp biomass and nitrogen production for a winter cover crop. International Journal of Agronomy, Volume 2011, Article ID 237510, 8 pages. https://doi.org/10.1155/2011/237510

Bernstein, E. R., Posner, J. L., Stoltenberg, D. E., \& Hedtcke, J. L. (2011). Organically managed no-tillage rye-soybean systems: Agronomic, economic, and environmental assessment. Agronomy Journal, 103, 1169-1179. https;//doi.org/10.2134/agronj2010.0498

Blanco-Canqui, H., Claassen, M. M., \& Presley, D. R. (2012). Summer cover crops fix nitrogen, increase crop yield, and improve soil-crop relationships. Agronomy Journal, 104, 137-147. https://doi.org/10.2134/agronj2011.0240

Blanco-Canqui, H., Mikha, M. M., Presley, D. R., \& Claassen, M. M. (2011). Addition of cover crops enhances no-till potential for improving soil physical properties. Soil Science Society of America. Journal, 75, 1471-1482. https://doi.org/10.2136/sssaj2010.0430

Blanco-Canqui, H., Shaver, T. M., Lindquist, J. L., Shapiro, C. A., Elmore, R. W., Francis, C. A., \& Hergert, G. W. (2015). Cover Crops and Ecosystem Services: Insights from Studies in Temperate Soils. Agronomy Journal, 107, 2449-2474.

Bradley, J. M., Chase, C., Koenig, R., Cho, A., Morales-Payan, J. P., Murphy, T., \& Antonious, G. F. (2015). Effect of sunn hemp (Crotolaria juncea L.) cutting date and planting density on weed suppression in Georgia, USA. Journal of Environmental Science and Health, 50(8), 614-621.

Cherr, C. M., Scholberg, J. M. S., \& McSorley, R. (2006). Green manure as nitrogen source for sweet corn in a warm-temperate environment. Agronomy Journal, 98, 1173-1180. https:doi.org/10.2134/agronj2005.0036

Clark, K. M., Boardman, D. L., Staples, J. S., Easterby, S., \& Reinbott, T. M. (2017). Crop yield and soil organic carbon in conventional and no-till organic systems on a claypan soil. Agronomy Journal, 109, 588-599.

Creamer, N. G., \& Dabney, S. M. (2002). Killing cover crops mechanically: Review of recent literature and assessment of new research results. American Journal of Alternative Agriculture, 17, 32-40. 
Dabney, S. M., Delgado, J. A., \& Reeves, D. W. (2001). Using winter cover crops to improve soil and water quality. Commun. Soil Sci. Plant Anal., 32, 1221-1250.

Garcia, R. A., Li, Y., \& Rosolem, C. A. (2013). Soil organic matter and physical attributes affected by crop rotation under no-till. Soil Science Society of America Journal, 77, 1724-1731.

Environmental Protection Agency. (2017). Climate impacts on agriculture and food supply. Retrieved June 19th, 2018. Retrieved from https://19january2017snapshot.epa.gov/climate-impacts/climate-impacts-agriculture-and-food-supply_html

Hubbard, R. K., Strickland, T. C., \& Phatak, S. (2013). Effects of cover crop systems on soil physical properties and Carbon/Nitrogen relationships in the coastal plain of southeastern USA. Soil \& Tillage Research, 126, 276-283.

Iizumi, T., \& Ramankutty, N. (2015). How do weather and climate influence cropping area and intensity. Global Food Security, 4, 46-50. https://doi.org/10.1016/j.gfs.2014.11.003

Islam, R., \& Reeder, R. (2014). No-till and conservation agriculture in the United States: An example from the David Brandt Farm, Carroll, Ohio. International Soil and Water Conservation Research, 2(1), 97-10.

Kaspar, T. C., \& Singer, J. W. (2011). The use of cover crops to manage soil. In: J. L. Hatfield and T.J. Sauer, editors, Soil management: Building a stable base for agriculture. SSSA, Madison, WI. https://doi.org/10.2136/2011.soilmanagement.c21

Keene, C. L., Curran, W. S., Wallace, J. M., Ryan, M. R., Mirsky, S. B., VanGessel, M. J., \& Barbercheck, M. E. (2017). Cover crop termination timing is critical in organic rotational no-till systems. Agronomy Journal, 109(1), 271-282.

Liebl, R., Simmons, F. W., Wax, L. M., \& Stoller, E. W. (1992). Effect of rye (Secale cereale) mulch on weed control and soil moisture in soybean (Glycine max). Weed Technology, 6, 838-846.

Mahama, G. Y., Vara Prasad, P. V., Roozeboom, K. L., Nippert, J. B., \& Rice, C. W. (2016). Response of maize cover crops, fertilizer nitrogen rates and economic return. Agronomy Journal, 108, 17-31.

Mansoer, Z., Reeves, D. W., \& Wood, C. W. (1997). Suitability of sunn hemp as an alternative late-summer legume cover crop. Soil Science Society of America Journal, 61, 246-253. https://doi.org/10.2136/sssaj1997.03615995006100010034x

Mirsky, S., Curran, W. S., Mortensen, D. A., Ryan, M. R., \& Shumway, D. (2009). Control of cereal rye with a roller/crimper as influenced by cover crop phenology. Agronomy Journal, 101, 1589-1596. https://doi.org/10.2134/agronj2009.0130

Mirsky, S. B., Ryan, M. R., Curran, W. S., Teasdale, J. R., Maul, J., \& Spargo, J. T. (2012). Conservation tillage issues: Cover crop-based organic rotational no-till grain production in the Mid-Atlantic region, USA. Renewable Agriculture Food Systems, 27, 31-40. https://doi.org/10.1017/ S1742170511000457

Mischler, R. A., Curran, W. S., Duiker, S. W., \& Hyde, J. A. (2010a). Use of a rolled-rye cover crop for weed suppression in no-till soybeans. Weed Technology, 24, 253- 261. https:/doi.org/10.1614/WT-D-09-00004.1

Mischler, R., Duiker, S. W., Curran, W. S., \& Wilson, D. (2010b). Hairy vetch management for no-till organic corn production. Agronomy Journal, 102, 355-362. https://doi.org/10.2134/agronj2009.0183

Mohler, C. L., \& Teasdale, J. R. (1993). Response of weed emergence to rate of Vicia villosa Roth and Secale cereale L. residue. Weed Research, 33, 487- 499. https://doi.org/10.1111/j.1365-3180.1993.tb01965.x

Mosjidis, J. A., \& Rehtji, G. (2011). Weed control in sunn hemp and its ability to suppress weed growth. Crop Protection, 30(1), 70-73.

Muneoz- Carpena, R., Ritter, A., Bosch, D. D., Schaffer, B., \& Potter, T. L. (2008). Summer cover crop impacts on soil percolation and nitrogen leaching from a winter corn field. Agricultural Water Management, 95(6), 633-644.

Natural Resource Conservation Service. (1999). Technical Note No.10, May 1999. Sunn Hemp: A cover crop for southern and tropical farming systems. Retrieved from https://www.nrcs.usda.gov/Internet/FSE_DOCUMENTS/nrcs142p2_053283.pdf

Parr, M., Grossman, J. M., Reberg-Horton, S. C., Brinton, C., \& Crozier, C. (2011). Nitrogen delivery from legume cover crops in no-till organic corn production. Agronomy Journal, 103, 1578-1590. https://doi.org/10.2134/agronj2011.0007 
Price, A. J., Kelton, J., \& Mosjidis, J. (2012). Utilization of sunn hemp for cover crops and weed in temperate climates. In Tech, 12, 101-114.

Rasmussen, I. A., Melander, B., Askegaard, M., Kristensen, K., \& Olesen, J. E. (2014). Elytrigia repens Population dynamics under different management schemes in organic cropping systems on coarse sand. European Journal of Agronomy, 58, 18-27. https://doi.org/10.1016/j.eja.2014.04.003

Rawls, W. J., Pachepsky, Y. A., Ritchie, J. C., Sobecki, T. M., \& Bloodworth, H. (2003). Effect of soil organic Carbon on soil water retention. Geoderma, 116, 61-76. https://doi.org/10.1016/S0016-7061(03)00094-6

Reinbott, T. M., Conley, S. P., \& Blevins, D. G. (2004). No-tillage corn and grain sorghum response to cover crop and nitrogen fertilization. Agronomy Journal, 96, 1158-1163. https;//doi.org/:10.2134/agronj2004.1158

Ruis, S. J., \& Blanco-Canqui, H. (2017). Cover crops could offset crop residue removal effects on soil carbon and other properties: A review. Agronomy Journal, 109, 1785-1805.

Schomberg, H. H., Martini, N. L., Diaz-Perez, J. C., Phatak, S. C., Balkcom, K. S., \& Bhardwaj, H. L. (2007). Potential for using sunn hemp as a source of biomass and nitrogen for the piedmont and coastal plain regions of the southeastern USA. Agronomy Journal, 99, 1448-1457.

https://doi.org/10.2134/agronj2006.0294

Smith, R. G., Barbercheck, M. E., Mortensen, D. A., Hyde, J., \& Hulting, A. G. (2011). Yield and net returns during the transition to organic feed grain production. Agronomy Journal, 103, 51-59.

https://doi.org/10.2134/ agronj2010.0290

Snapp, S. S., Swinton, S. M., Labarta, R., Mutch, D., Black, J. R., Leep, R., Nyiraneza, J., \& O’Neil, K. (2005). Evaluating cover crops for benefits, costs and performance within cropping system niches. Agronomy Journal, 97, 322-332.

Stallings, A. M., Balkcom, K. S., Wood, C. W., Guertal, E. A. A., \& Weaver, D. B. (2017). Nitrogen mineralization from ‘AU Golden' sunn hemp residue. Journal of Plant Nutrition, 40(1), 50-62.

Stute, J. K. (2017). Michael Fields Agricultural Institute. Unpublished data.

Teasdale, J. R., Coffman, C. B., \& Mangum, R. W. (2007). Potential long-term benefits of no-tillage and organic cropping systems for grain production and soil improvement. Agronomy Journal, 99, 1297-1305. https://doi.org/10.2134/agronj2006.0362

United States Department of Agriculture. (2018). Retrieved from https://www.fsa.usda.gov/news-room/efoia/ele ctronic-reading-room/frequently-requested-information/crop-acreage-data/index

United States Department of Agriculture Handbook. (2018). Prevented Planting Standards Handbook. Retrieved from https://www.rma.usda.gov/handbooks/25000/2018/18_25370.pdf

Veenstra, J. J., Horwath, W. R., \& Mitchell, J. P. (2007). Tillage and cover cropping effects on aggregate-protected carbon in cotton and tomato. Soil Science Society of America Journal, 71, 362-371. https://doiorg/10.2136/sssaj2006.0229

Warren, J., Wilson, T., \& Edwards, J. (2017). Using sunn hemp as a cover crop in Oklahoma. Retrieved from https://www.southernsare.org/Educational-Resources/SARE-Project-Products/Fact-Sheets/Using-Sunn-Hem p-as-a-Cover-Crop-in-oklahoma

Weinert, T. L., Pan, W. L., Moneymaker, M. R., Santo, G. S., \& Stevens, R. G. (2002). Nitrogen recycling by non-leguminous winter cover crops to reduce leaching in potato rotations. Agronomy Journal, 94, 365-372. https://doi.org/10.2134/agronj2002.0365

Wortman, S. E., Francis, C. A., \& Lindquist, G. L. (2012a). Cover crop mixtures for the western Corn Belt: Opportunities for increased productivity and stability. Agronomy Journal, 104, 699-705. https://doi.org/10.2134/agronj2011.0422

Wortman, S. E., Francis, C. A., Bernards, M. L., Drijber, R. A., \& Lindquist, J. L. (2012b). Optimizing cover crop benefits with diverse mixtures and an alternative termination method. Agronomy Journal, 104, 1425-1435.

\section{Copyrights}

Copyright for this article is retained by the author(s), with first publication rights granted to the journal.

This is an open-access article distributed under the terms and conditions of the Creative Commons Attribution license (http://creativecommons.org/licenses/by/3.0/). 